\title{
The effects of $B$ cell depletion on immune related adverse events associated with immune checkpoint inhibition
}

\author{
Rasmus Strøm Risbjerg ${ }^{1 \dagger}$, Mie Vennize Hansen ${ }^{1 \dagger}$, Anne Sofie Sørensen ${ }^{1}$ and Tue Wenzel Kragstrup ${ }^{1,2^{*}}$ (c)
}

\begin{abstract}
This letter describes the potential effect of B cell depletion on immune related adverse events associated with immune checkpoint inhibition. B cell depleting agents such as rituximab reduce B cell to plasma cell differentiation and antibody production. This treatment strategy is used in several immune mediated inflammatory diseases such as rheumatoid arthritis and small vessel vasculitis. The immune related adverse events associated with immune checkpoint inhibition resemble immune mediated inflammatory diseases. Here, we report a lower incidence of hypothyroidism in a trial of combined B cell depletion and immune checkpoint inhibitor treatment compared with studies of immune checkpoint inhibitor monotherapy. This letter aims to increase awareness of the immune related adverse events associated with immune checkpoint inhibition in future clinical trials of immune checkpoint inhibition together with B cell depletion (primarily trials of B cell lymphomas). Hopefully, observations from these clinical trials can guide future treatment strategies to treat or prevent immune related adverse events associated with immune checkpoint inhibition.
\end{abstract}

Keywords: B cell depletion, Immune checkpoint inhibition, Immune related adverse events, Immune mediated inflammatory disease, Hypothyroidism

The next decade will bring fundamental knowledge about the immunology behind the immune related adverse events (irAEs) associated with immune checkpoint inhibition (ICI). This knowledge will come as a consequence of new clinical trials of ICI together with B cell depletion. These treatment regimens are designed to improve outcomes for patients with B cell hematologic malignancies. However, reports of the irAE profile will be a major addon benefit from these clinical trials.

During ICI 35\% of cancer patients develop irAEs. This type of adverse events resembles immune mediated inflammatory diseases (IMIDs). When treating cancer,

\footnotetext{
*Correspondence: kragstrup@biomed.au.dk

${ }^{\dagger}$ Rasmus Strøm Risbjerg and Mie Vennize Hansen contributed equally

${ }^{1}$ Department of Biomedicine, Aarhus University, Skou Building, 8000 Aarhus C, Denmark

Full list of author information is available at the end of the article
}

we try to induce immunological reactions against the tumor cells. When treating IMIDs, we try to dampen immunological reactions causing inflammation. Immune modulating therapy can therefore be a double-edged sword. However, the two processes might not be mutually exclusive.

ICI refers to blocking antibodies targeting the programmed cell death protein 1 (PD1) and cytotoxic T-lymphocyte-associated protein 4 (CTLA4) pathways. PD1 and CTLA4 are negative regulators of $\mathrm{T}$ cell activity and are upregulated in many malignancies. In this way, cancer cells evade immune surveillance. ICI results in increased activity of the immune system and increased recognition and elimination of cancer cells. Therefore, ICI is emerging as a potential treatment option for many malignancies including lymphoma. B cell depleting agents bind to $B$ cell specific membrane proteins causing

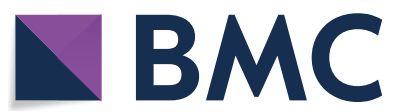

(c) The Author(s) 2020. This article is licensed under a Creative Commons Attribution 4.0 International License, which permits use, sharing, adaptation, distribution and reproduction in any medium or format, as long as you give appropriate credit to the original author(s) and the source, provide a link to the Creative Commons licence, and indicate if changes were made. The images or other third party material in this article are included in the article's Creative Commons licence, unless indicated otherwise in a credit line to the material. If material is not included in the article's Creative Commons licence and your intended use is not permitted by statutory regulation or exceeds the permitted use, you will need to obtain permission directly from the copyright holder. To view a copy of this licence, visit http://creativecommons.org/licenses/by/4.0/. The Creative Commons Public Domain Dedication waiver (http://creativecommons.org/publicdomain/zero/1.0/) applies to the data made available in this article, unless otherwise stated in a credit line to the data. 
complement-dependent cytotoxicity and antibodydependent cellular cytotoxicity. E.g. rituximab binds to CD20 found on mature B cells and is routinely used in the treatment of $B$ cell lymphomas. This results in depletion of the cancerous $B$ cells expressing the $C D 20$ protein on their surface. However, depletion of all mature $B$ cells will also reduce antigen presentation, $B$ cell to plasma cell differentiation and antibody production. Therefore, rituximab is also used in the treatment of several IMIDs such as rheumatoid arthritis and small vessel vasculitis.

Little is known about the immunological reactions causing irAEs. Some irAEs are associated with the presence of autoantibodies implying a role for B cells. The most frequent of these autoantibody-associated irAEs is thyroiditis.

Until now, only one clinical trial combining ICI with B cell depletion has been completed. 2 To investigate whether rituximab alters the frequency of irAEs we compared the incidence of hypothyroidism in this phase II trial with the incidence of hypothyroidism in comparable studies of PD1 inhibitor monotherapy.

The completed phase II clinical trial was a study of 32 patients with rituximab-sensitive follicular lymphoma treated with pidilizumab and rituximab [1]. Pidilizumab was administered at $3 \mathrm{mg} / \mathrm{kg}$ intravenously every 4 weeks for 4 infusions. Furthermore, eight optional infusions every 4 weeks were available for patients with stable disease or tumor regression. Rituximab infusions were administered at $375 \mathrm{mg} / \mathrm{m}^{2}$ intravenously 17 days after the first infusion of pidilizumab and weekly for 4 weeks. Of the 32 patients, two were ineligible and not treated. Thirty patients were available for toxicity analysis, but only 29 received the therapy. The incidence of hypothyroidism in the 29 patients that received combination therapy was $0 \%$ (confirmed by personal correspondence with the authors).

This incidence contrasts with larger studies with PD1 inhibition monotherapy reporting between $6 \%$ and $10 \%$ of patients experiencing hypothyroidism (Table 1) [2-4] The studies in Table 1 were selected to best match the phase II combination therapy trial in regard to PD1 monotherapy and follow-up time. Therefore, the inclusion criteria were (1) treatment with PD1 inhibitor monotherapy, (2) follow-up time of around 15 weeks, (3) more than 200 patients included and toxicity result available for hypothyroidism.

Table 1 Characteristics and adverse events from ICI monotherapy studies

\begin{tabular}{llllll}
\hline Study & Patients & Therapy (dose) & $\begin{array}{l}\text { Hypothyroid events } \\
\text { of any grade (\%) }\end{array}$ & $\begin{array}{l}\text { Hypothyroid events } \\
\text { of grade 3-5 }\end{array}$ & Median follow-up (range) \\
\hline Westin [1] & 29 & Pidilizumab (3 mg/kg) & $0(0)$ & 0 & 15.4 months \\
Weber [2] & 452 & Nivolumab (3 mg/kg) & $49(10.8)$ & 1 & 19.5 months/13 months \\
Bellmunt [3] & 266 & Pembrolizumab & $17(6.4)^{\mathrm{b}}$ & 0 & 14.1 months \\
Herbst [4] & 339 & Pembrolizumab (2 mg/kg) & $28(8.3)$ & 0 & 13.1 months (8.6-17-7) \\
\hline
\end{tabular}

${ }^{a}$ Adverse events were reported up to 30 days after last treatment and treatment duration was up to 12 months at a maximum, for that reason follow-up time regarding adverse events can add up to no more than 13 months

b 10 patients (3.8\%) experienced hyperthyroidism

Table 2 List of ongoing PD-1 inhibition and rituximab combination therapy studies

\begin{tabular}{lrlllll}
\hline Study (NCT) & Phase & Patients & ICl & Study start & Study completion & Conditions treated \\
\hline NCT02541565 & 1 & 33 & Pembrolizumab & November 2015 & December 18, 2018 ${ }^{\mathrm{a}}$ & DLBCL, FL \\
NCT03259529 & $1 / 2$ & 30 & Nivolumab & March 2017 & December 27, 2020 & DLBCL \\
NCT03749018 & 2 & 30 & Nivolumab & January 2019 & December 31, 2021 & B-cell non-Hodgkin lymphoma \\
NCT03704714 & $1 / 2$ & 30 & Nivolumab & November 2018 & June 11, 2022 & DLBCL \\
NCT03719131 & 2 & 44 & Nivolumab & June 2019 & October 31, 2022 & Stage IIIIV melanoma \\
NCT03630042 & 2 & 42 & Pembrolizumab & August 2019 & April, 2023 & Waldenström's macrogloulinamia \\
NCT03934814 & 1 & 88 & Pembrolizumab & May 2019 & September 23, 2023 & Solid tumors, DLBCL, indolent lymphoma \\
NCT02677155 & 2 & 20 & Pembrolizumab & January 2016 & January, 2024 & $\mathrm{FL}$ \\
NCT03245021 & 1 & 39 & Nivolumab & September 2017 & June, 2024 & $\mathrm{FL}$ \\
NCT03995147 & 2 & 51 & Pembrolizumab & August 2019 & August 20, 2024 & DLBCL \\
NCT03121677 & 1 & 20 & Nivolumab & October 2018 & January 31, 2028 & $\mathrm{FL}$ \\
\hline
\end{tabular}

$D L B C L$ diffuse large B-cell lymphoma, $F L$ follicular lymphoma

a No results posted 
The general purpose of ICI is to induce immunological reactions against the tumor cells. Therefore, any treatment of irAEs will potentially compromise the antitumor response. It is not known whether concurrent use of $B$ cell depletion therapy reduces the efficacy of immunotherapy in non-B cell lymphoma malignancies.

Obviously, the small sample size of the completed phase II clinical trial (29 patients) is a major limitation. Thyroiditis was chosen because it is one of the most frequent irAE. We did not compare any of the other irAEs. This letter primarily aims to increase awareness of the irAEs associated with ICI in future clinical trials of ICI together with B cell depletion. A list of these ongoing trials and their completion dates can be seen in Table 2 . The ongoing trials were found on clinicaltrials.gov by searching for 'rituximab,' 'obinutuzumab' or 'ofatumumab' together with 'pidilizumab', 'nivolumab' or 'pembrolizumab' including only clinical trials with a treatment arm combining CD20 targeted antibody and PD1 inhibition. Hopefully, observations from these clinical trials can guide future treatment strategies to treat or prevent irEAs associated with ICI.

\section{Abbreviations}

CTLA4: Cytotoxic T-lymphocyte-associated protein 4; ICl: Immune checkpoint inhibition; IMID: Immune mediated inflammatory disease; irAE: Immune related adverse events; PD1: Programmed cell death protein 1.

\section{Acknowledgements}

We thank Professor Jason Robert Westin (Department of Lymphoma \& Myeloma, M.D. Anderson Cancer Center, Houston, USA) for sharing data from the phase 2 clinical trial combining $\mathrm{ICI}$ with $\mathrm{B}$ cell depletion.

\section{Authors' contributions}

TWK helped to design the study and analyze and interpret the data. RSR, MVH and ASS helped to analyze and interpret the data and draft the manuscript. All authors read and approved the final manuscript.

\section{Funding}

TWK is supported by Independent Research Fund Denmark clinical investigator Grant (9039-00015B).

\section{Availability of data and materials Not applicable.}

Ethics approval and consent to participate Not applicable.
Consent for publication

Not applicable.

\section{Competing interests}

TWK has engaged in educational activities talking about immunology in rheumatic diseases receiving speaking fees from Pfizer, speaking fees from Bristol-Myers Squibb, speaking fees from Eli Lilly, speaking fees from Novartis, and speaking fees from UCB and has received a consultancy fee from Bristol-Myers Squibb. TWK is co-owner and clinical developer at the start-up company iBIO TECH ApS developing diagnostics and medicines for the treatment of immune mediated inflammatory disease. These engagements do not cause direct conflicts of interest concerning this study. The rest of the authors declare no potential conflicts of interest relevant to this article.

\section{Author details}

${ }^{1}$ Department of Biomedicine, Aarhus University, Skou Building, 8000 Aarhus C, Denmark. ${ }^{2}$ Department of Rheumatology, Aarhus University Hospital, Aarhus, Denmark.

Received: 26 March 2020 Accepted: 19 May 2020

Published online: 25 May 2020

\section{References}

1. Westin JR, Chu F, Zhang M, et al. Safety and activity of PD1 blockade by pidilizumab in combination with rituximab in patients with relapsed follicular lymphoma: a single group, open-label, phase 2 trial. Lancet Oncol. 2014;15(1):69-77.

2. Weber J, Glutsch V, Geissinger E, et al. Neoadjuvant immunotherapy with combined ipilimumab and nivolumab in melanoma patients with primary or in-transit disease. Br J Dermatol. 2019. https://doi.org/10.1111/ bjd.18739.

3. Nishiyama H, Yamamoto Y, Sassa N, et al. Pembrolizumab versus chemotherapy in recurrent, advanced urothelial cancer in Japanese patients: a subgroup analysis of the phase 3 KEYNOTE-045 trial. Int J Clin Oncol. 2019:25(1):165-74.

4. Herbst RS, Baas P, Kim DW, et al. Pembrolizumab versus docetaxel for previously treated, PD-L1-positive, advanced non-small-cell lung cancer (KEYNOTE-010): a randomised controlled trial. Lancet. 2016:387(10027):1540-50

\section{Publisher's Note}

Springer Nature remains neutral with regard to jurisdictional claims in published maps and institutional affiliations.

\footnotetext{
Ready to submit your research? Choose BMC and benefit from:

- fast, convenient online submission

- thorough peer review by experienced researchers in your field

- rapid publication on acceptance

- support for research data, including large and complex data types

- gold Open Access which fosters wider collaboration and increased citations

- maximum visibility for your research: over 100M website views per year

At BMC, research is always in progress.

Learn more biomedcentral.com/submissions
} 